\title{
Update and clinical utility of the LenSx femtosecond laser in cataract surgery
}

\author{
This article was published in the following Dove Press journal: \\ Clinical Ophthalmology \\ 17 October 2016 \\ Number of times this article has been viewed
}

\author{
Timothy V Roberts ${ }^{1,2}$ \\ Michael Lawless ${ }^{1,2}$ \\ Gerard Sutton ${ }^{1,2}$ \\ Chris Hodge ${ }^{1,3}$ \\ 'Vision Eye Institute, Chatswood, \\ ${ }^{2}$ Sydney Medical School, University \\ of Sydney, ${ }^{3}$ Graduate School of \\ Health Sciences, University of \\ Technology, Sydney, NSW, Australia
}

\begin{abstract}
The introduction of femtosecond lasers to cataract surgery has been the major disruptive technology introduced into ophthalmic surgery in the last decade. Femtosecond laser cataract surgery (FLACS) integrates high-resolution anterior segment imaging with a femtosecond laser allowing key steps of cataract surgery to be performed with computer-guided laser accuracy, precision, and reproducibility. Since the introduction of FLACS, there have been significant advances in laser software and hardware as well as surgeon experience, with over 250 articles published in the peer-reviewed literature. This review examines the published evidence relating to the LenSx platform and discusses surgical techniques, indications, safety, and clinical results.
\end{abstract}

Keywords: femtosecond laser, cataract surgery, LenSx, IOL

\section{Introduction}

The introduction of femtosecond lasers to cataract surgery has been the major disruptive technology introduced into ophthalmic surgery in the last decade. Femtosecond laser cataract surgery (FLACS) integrates high-resolution anterior segment imaging with a femtosecond laser allowing key steps of the procedure to be performed with computer-guided laser accuracy, precision, and reproducibility. There are currently five femtosecond laser platforms available and approved for use during cataract surgery. The LenSx platform (Alcon Laboratories, Inc., Fort Worth, TX, USA) was the first laser to obtain both the US (Food and Drug Administration) and European (Conformité Européene, CE Mark) approval and was commercially released in 2011. Since then, more than 950 laser platforms have been installed in 67 countries with 3,500 surgeons trained and over 800,000 procedures completed using the LenSx. The scientific literature has provided over 250 peer-reviewed articles, ranging from randomized controlled trials to cohort studies, case reports, and editorials. This review examines the published evidence relating to the LenSx platform and discusses surgical techniques, indications, and clinical results relating to capsulotomy, phacoemulsification and lens fragmentation, corneal wound creation, and visual results. Safety issues relating to capsular integrity and corneal endothelial and macular changes are also discussed.

\section{Technical aspects of the LenSx femtosecond laser}

The Alcon LenSx femtosecond laser represents a conventionally amplified solid-state laser. The laser beam is directed by means of an integrated video microscope and high-definition optical coherence tomography (OCT) scanner. The laser is connected (docked) to the patient via the use of a patient interface (PI). The type of PI is significantly different between the available laser platforms. The LenSx laser uses a curved
Correspondence: Timothy $\mathrm{V}$ Roberts Vision Eye Institute, Level 3, 270 Victoria Avenue, Chatswood, NSW 2067, Australia Email tim.roberts@visioneyeinstitute. com.au (c) (1) (5) 2016 Roberts et al. This work is published and licensed by Dove Medical Press limited. The full terms of this license are available at https://www.dovepress.com/terms.php

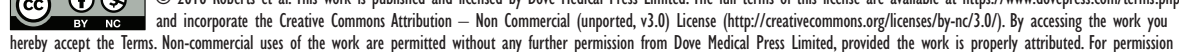
for commercial use of this work, please see paragraphs 4.2 and 5 of our Terms (https://www.dovepress.com/terms.php). 

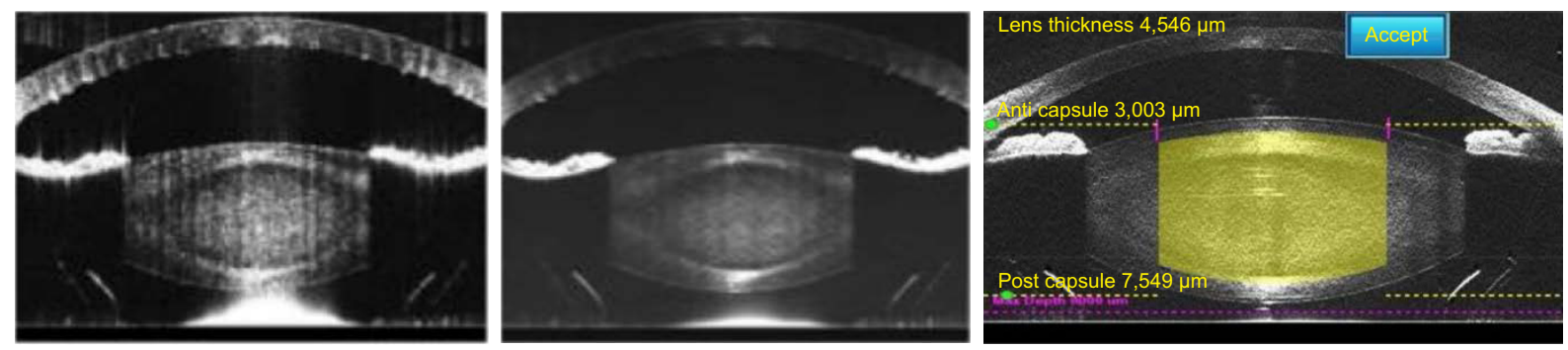

Figure I Improved optical coherence tomography imaging with software advances.

Notes: The left and middle images show OCT scans obtained with earlier software. The resolution is limited and posterior corneal folds are evident. The right hand image shows high resolution scans of the lens and cornea using the SoftFit interface with significantly less compression of the cornea and elimination of posterior corneal folds. Abbreviation: OCT, optical coherence tomography.

contact lens which is integrated with a sterile limbal suction ring (SoftFit PI). The common alternative used in other laser platforms is a noncontact liquid optical interface. The treatment pattern is localized by a combination of the live video and OCT prior to the start of the laser ablation. The surgeon is able to choose from a variety of treatment parameters and may alter the position and architecture of the corneal incisions, centration, and diameter of the anterior capsulotomy and further, the depth and type of fragmentation pattern (Figures 1 and 2). Recent software advances provide the surgeon with the ability to couple the Verion pre-assessment system (Alcon Laboratories, Inc.) with the LenSx unit, providing enhanced automatic recognition and centration utilizing both conjunctival and scleral vessels as well as iris characteristics. Since the first commercially available LenSx platform was introduced into the marketplace, other platforms have become available (Table 1), and new spin-off technologies for laser capsulotomy and capsulotomy-fixated intraocular lens (IOLs) are being developed.

\section{Intraoperative uses}

Femtosecond laser technology has been approved to facilitate corneal incisions, capsulotomy, and lens fragmentation processes. The relative advantages and disadvantages of each process are discussed with reference to the available supporting literature.

\section{Docking}

Accurate docking is essential to the success of the FLACS procedure as poor or inadequate docking affects all aspects of the femtosecond laser process. ${ }^{1}$ The PI acts as a coupling device allowing the efficient delivery of the laser beam to the targeted ocular tissue as well as maintaining mechanical stability of the eye during laser delivery. Talamo et al previously showed that rigid PIs may lead to corneal folds which can precipitate lateral shifts of the laser beam, degrading the quality of the focus for both the imaging and the treatment beams. ${ }^{2}$ Directly, this may lead to incomplete laser corneal incisions and capsulotomies. Mayer et al found that manual opening of corneal incisions was required in 21 out of 85 eyes with a curved direct contact PI. Only 9 out of 115 cases of the corresponding group of patients who used a modified interface with a soft contact lens (SoftFit) required manual opening of corneal incisions. Further, the authors described intraoperative wrinkling in almost half of the direct contact PI eyes leading to one anterior capsule tear. ${ }^{3}$ Neither corneal wrinkling nor capsular tears were found in the SoftFit PI group. Talamo et al confirmed these findings in addition to showing no significant difference in terms of eye movement under the fluid interface compared to the rigid alternative. ${ }^{2}$

Some authors have speculated that the transient intraocular pressure (IOP) rise associated with docking may lead to potential optic disc damage in at-risk patients. ${ }^{4}$ The current
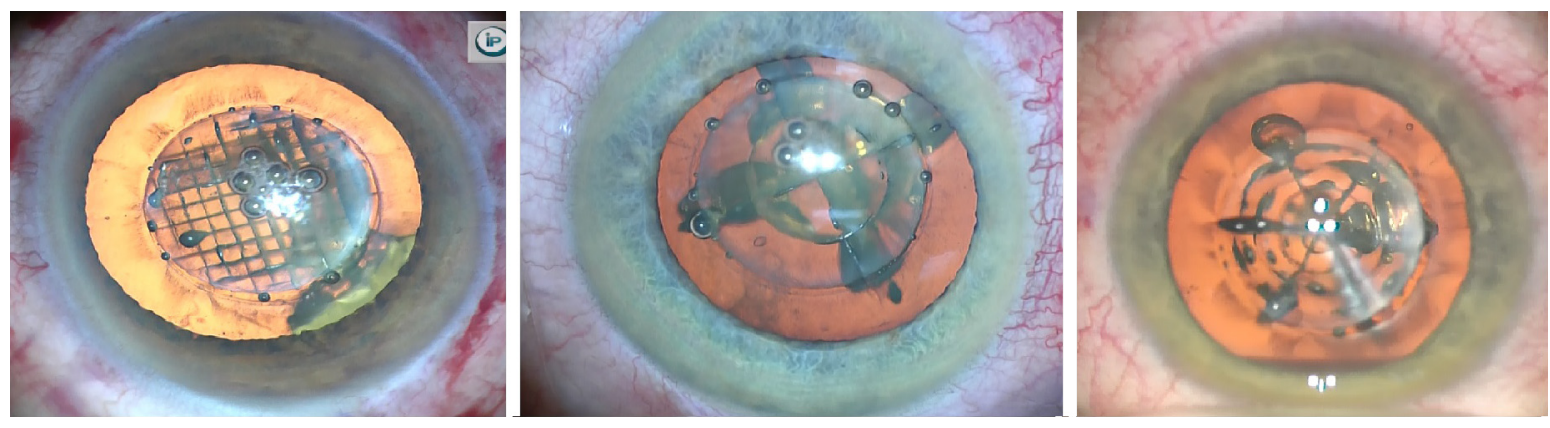

Figure 2 Fragmentation patterns.

Note: The left image shows a cube pattern and the middle and right images show hybrid cylindrical-spoke patterns. 
Table I Commercially available femtosecond laser cataract platforms

\begin{tabular}{|c|c|c|c|c|c|}
\hline Laser & Approval & Patient interface & Imaging & $\begin{array}{l}\text { Pulse } \\
\text { frequency }(\mathbf{k H z})\end{array}$ & IOP rise \\
\hline $\begin{array}{l}\text { LenSx (Alcon } \\
\text { Laboratories, Inc., } \\
\text { Fort Worth, TX, USA) }\end{array}$ & $\begin{array}{l}\text { Incisions } \\
\text { Phacofragmentation } \\
\text { Capsulotomy } \\
\text { Corneal flap }\end{array}$ & SoftFit contact lens & $\begin{array}{l}\text { 3D spectral } \\
\text { domain OCT and } \\
\text { image-guided laser }\end{array}$ & 50 & $16 \mathrm{mmHg}$ \\
\hline $\begin{array}{l}\text { Catalys (Abbott, } \\
\text { Chicago, IL, USA) }\end{array}$ & $\begin{array}{l}\text { Incisions } \\
\text { Phacofragmentation } \\
\text { Capsulotomy }\end{array}$ & $\begin{array}{l}\text { Liquid optics } \\
\text { interface }\end{array}$ & $\begin{array}{l}\text { 3D spectral } \\
\text { domain OCT and } \\
\text { image-guided laser }\end{array}$ & 120 & $10 \mathrm{mmHg}$ \\
\hline $\begin{array}{l}\text { LensAR (LensAR, } \\
\text { Orlando, FL, USA) }\end{array}$ & $\begin{array}{l}\text { Incisions } \\
\text { Phacofragmentation } \\
\text { Capsulotomy }\end{array}$ & $\begin{array}{l}\text { Non-applanating } \\
\text { fluid interface }\end{array}$ & $\begin{array}{l}\text { 3D ray-tracing } \\
\text { confocal structural } \\
\text { illumination }\end{array}$ & 80 & $40 \mathrm{mmHg}$ \\
\hline $\begin{array}{l}\text { Victus (Bausch \& Lomb, } \\
\text { Rochester, NY, USA) }\end{array}$ & $\begin{array}{l}\text { Incisions } \\
\text { Capsulotomy } \\
\text { Corneal flap }\end{array}$ & $\begin{array}{l}\text { Dual modality (liquid } \\
\text { vacuum for cataract) }\end{array}$ & $\begin{array}{l}\text { 3D spectral OCT } \\
\text { guided }\end{array}$ & Up to 160 & Undisclosed \\
\hline $\begin{array}{l}\text { LDV Z8 (Ziemer } \\
\text { Ophthalmic Systems } \\
\text { AG, Biel, Switzerland) }\end{array}$ & $\begin{array}{l}\text { Incisions } \\
\text { Phacofragmentation } \\
\text { Capsulotomy } \\
\text { Corneal flap } \\
\text { PKP }\end{array}$ & $\begin{array}{l}\text { Liquid patient } \\
\text { interface }\end{array}$ & Proprietary OCT & $>5 \mathrm{MHz}$ & $30 \mathrm{mmHg}$ \\
\hline
\end{tabular}

Abbreviations: IOP, intraocular pressure; 3D, three-dimensional; OCT, optical coherence tomography; PKP, penetrating keratoplasty.

SoftFit PI increases the IOP by approximately $16 \mathrm{mmHg}$ and is applied for only 1-2 minutes (Alcon Laboratories, Inc., data on file, 2016). At this point, no short- or long-term complications directly related to this IOP rise have been reported. Patients with well-controlled glaucoma or other optic neuropathies may not, therefore, be at a significant risk for progressive optic neuropathy; however, a comprehensive discussion of the potential risks and benefits of FLACS should be undertaken in all patients with optic nerve disease. ${ }^{5}$

\section{Laser capsulotomy}

A well-centered, intact, circular capsulotomy is critical to the safety and efficacy of cataract surgery and is recognized as the most difficult step of manual phacoemulsification by trainee surgeons. ${ }^{6}$ A circular, properly constructed capsulorhexis allows the capsular bag to completely envelop the IOL optic reducing the incidence of possible posterior capsule opacification (PCO) and providing a more predictable effective lens position. ${ }^{7}$ Achieving a consistently sized and shaped capsulotomy with greater precision appears to be a significant advantage of FLACS. ${ }^{8-10}$

Although commercially available laser platforms differ in terms of laser characteristics, treatment algorithms, and docking systems, the literature indicates that all femtosecond laser-generated capsulotomies are more precise than a manual capsulorhexis, providing better centration and uniform IOL optic overlap..$^{9-15}$ The impact of these features upon refractive results may be cumulative. Kranitz et al, using the LenSx laser, previously found that this was associated with less horizontal and vertical lens tilt compared with manually created capsulorhexes. ${ }^{16}$ This led to significantly improved corrected and uncorrected vision in their laser cohort. Further, the same group described less induced internal aberrations, attributed to reduced tilt, thereby leading to improved postoperative visual acuity and quality of vision over a manual cohort. ${ }^{17}$ In an additional study, Filkorn et al suggested that the capsulotomy resulted in a more stable IOL position, confirmed by the increased predictability of their refractive outcomes in a comparative study. ${ }^{18}$ As additional support, Toto et al more recently showed that patients undergoing FLACS showed less variability of anterior chamber (AC) depth compared to a conventional cataract surgery cohort. ${ }^{19}$ This provided a more stable postoperative refraction for the FLACS cohort at all time points, albeit there was no significant difference in the mean absolute error between groups. These findings may suggest future potential benefits for the refinement of IOL calculation formulas.

IOL positioning is essential in minimizing residual ammetropia and unwanted photic phenomena and enhancing the quality and contrast of the image..$^{20,21}$ The precision of laser capsulotomies is particularly beneficial with premium multifocal and trifocal IOLs, which demand greater alignment within the eye to maximize efficiency. Lawless et al showed a significantly greater percentage of patients achieving unaided visual acuity of 20/25 or better, despite no difference in the refractive outcomes, in a comparative cohort of patients with a diffractive multifocal IOL. ${ }^{22}$

The debate regarding the relative strength of the laser capsulotomy and the potential contribution to intraoperative 
complications remains ongoing. Early reports suggested that FLACS capsulotomies show increased strength and rupture force compared to manual capsulorhexis. ${ }^{12,23}$ However, Abell et al described a significantly higher incidence of anterior capsule tears using the Catalys platform compared to their manual cohort and hypothesized that the integrity of the lasercreated capsulotomy might be compromised by postagestamp perforations due to aberrant pulses. ${ }^{24}$ Other studies confirm that laser-generated capsulotomies have a different ultrastructural appearance to a torn manual capsulorhexis..$^{25-27}$ Bala et al found that the LenSx SoftFit platform appeared to show the least anomalies and most closely approached the appearance of a manual capsulorhexis. ${ }^{25}$

Subsequent clinical findings reported in the literature do not support the hypothesis of an instrinsically weak capsulotomy. Historical reports of anterior capsule tears have varied between $0.79 \%$ and $6.7 \%$ for experienced and non-experienced surgeons. ${ }^{28-31}$ A review of available national databases suggested that a capsular tear incidence rate of $2 \%$ is expected in manual surgical cases. ${ }^{32}$ During the learning curve with first-generation femtosecond laser technology, the authors observed a capsular tear rate of $4 \% .{ }^{33}$ With recent software and hardware advances, the incidence was reduced to $0.2 \%$ overall and less than $0.1 \%$ with the SoftFit PI. ${ }^{9}$ Similar results with other laser platforms suggest no additional clinical evidence of an intrinsically weak lasercut capsule. , $^{8,34}$

Early studies found that radial anterior capsule tears were more likely to result from a microtag being stretched and torn during intracapsular manipulation, and the authors recommended inspecting the edge of the laser-cut capsulotomy for a capsular tag under higher magnification before phacoemulsification. Routinely identifying these potential high-risk cases reduced the incidence of AC tears as the surgical technique could be altered to minimize capsular stress by dividing the nucleus into small segments, not stretching the capsule edge during cross-action manipulation with the phaco handpiece and side instrument and ensuring meticulous attention was given to maintaining a stable AC to prevent trampolining of the capsule and iris.

Toto et al evaluated cellular inflammation and apoptosis in laser and manual capsulotomies. ${ }^{36}$ Their results suggested that increasing laser energy levels correlated with increased inflammatory responses. The optimization of laser energy levels will further reduce intraoperative responses, albeit this represents only a portion of the surgical procedure. Kovacs et al have hypothesized that the superior centration and overlap provided by the laser capsulotomy may reduce the long-term incidence of PCO. In a comparative study using the LenSx laser, the authors showed, after adjusting for age, axial length, and follow-up time, that manual capsulorhexis was a significant predictor of higher PCO ${ }^{37}$ The sample size was relatively small and the follow-up limited to 26 months, and further studies will be needed to confirm this benefit. Wertheimer et al recently suggested that the development of PCO may be technique dependent; however, similarly, the authors acknowledge that additional studies are required. ${ }^{38}$ The observation of most surgeons is that with experience and improved settings and technology, FLACS results in a consistently round, intact, accurately sized laser-cut capsulotomy.

\section{Phacofragmentation}

A significant advantage of FLACS is the reduction in phacoemulsification time and energy ${ }^{1}$ with reports of zero effective phacoemulsification time (EPT). ${ }^{39-42}$ Comparative reductions in EPT within the literature between FLACS and manual cohorts are between $29 \%$ and $96 \%$ depending on laser platform and fragmentation patterns. ${ }^{11,39,41,43}$ The continued evolution of the technology is likely to further enhance these differences. Nagy and McAlinden recently described the customization of laser fragmentation patterns with the LenSx laser to the type and density of the cataract. ${ }^{44}$ The advancement of OCT technology will further enable the surgeon to identify the most appropriate intraoperative technique promoting safer and potentially better refractive outcomes.

The safety benefits of reduced EPT include less central corneal endothelial cell loss, corneal edema, and AC inflammation during the postoperative period. ${ }^{45-48}$ Literature supporting an additional benefit for macular safety remains mixed. Nagy et al showed a significant difference in peripheral macular thickness between FLACS and manual cohort, ${ }^{49}$ whereas another single-surgeon study found an increase in cystoid macular edema (CME) in eyes that underwent FLACS. ${ }^{50,51}$ Other multicenter studies have found no difference in the incidence of CME between manual and FLACS cohorts. ${ }^{52}$ It is unclear whether individual surgical technique and laser settings explain the higher rate of CME reported by Ewe et al. ${ }^{50}$

\section{Corneal incisions}

Femtosecond lasers provide corneal incisions of unparalleled precision and reproducibility compared to manual techniques. Masket et al previously showed that manually created incisions were less stable and more likely to result in leakage post-surgery. ${ }^{53}$ Mastropasqua et al showed that femtosecond 
laser-created incisions led to less endothelial gaping and misalignment compared to manual incisions. ${ }^{54}$ Whether this anatomical feature will translate into a reduced rate of postoperative wound leak or endophthalmitis remains to be seen. Mastropasqua et al also reported a lower increase of corneal thickness at the incision site at both 30 and 180 days postoperatively in the FLACS group compared to the manual group. ${ }^{54}$ Mayer et al showed no statistical difference in the local inflammatory cell response between incision groups; however, cell apoptosis was significantly pronounced in the femtosecond group at 12 hours post-incision. ${ }^{55}$

Several studies have analyzed the refractive impact of femtosecond laser incisions. Nagy et al found no difference in either the surgical-induced astigmatism or the induction of higher order aberrations between manual and FLACS cohorts. ${ }^{56}$ The use of laser-guided arcuate incisions has provided a significant reduction in postoperative residual astigmatism. In a small, early series, Donnenfeld showed that up to $86 \%$ of eyes had residual astigmatism of less than $0.5 \mathrm{D}$ following laser-guided arcuate incisions. ${ }^{57}$ Refinement of existing nomograms will lead to an improved consistency in outcomes and further benefit the understanding of refractive incisional effects. The use of coexisting technology such as intraoperative wavefront aberration (Alcon Laboratories, Inc.) may provide additional benefits providing surgeons with the ability to immediately titrate the refractive effect with greater control and precision.

\section{Refractive outcomes}

Filkorn et al were the first group to demonstrate a significant clinical refractive benefit of FLACS. They found a lower mean absolute error and standard deviation in patients undergoing FLACS as compared to manual surgeries $(0.38 \pm 0.28 \mathrm{D}$ vs $0.50 \pm 0.38 \mathrm{D}$ for FLACS and manual eyes, respectively). ${ }^{18}$ Interestingly, the benefit was greater in eyes with long and short axial lengths highlighting the potential advantage of the FLACS in providing predictable lens position and stability. Mastropasqua et al similarly described a smaller mean residual refraction and mean absolute error in the FLACS cohort; however, this did not result in significantly different uncorrected or corrected distance visual acuity. ${ }^{15}$ ConradHengerer et al showed a statistically greater percentage of patients achieving postoperative refraction $\pm 0.5 \mathrm{D}$ in their comparative study (90 eyes at $91 \%$ for FLACS cohort $\pm 0.5 \mathrm{D}$ compared to 70 eyes at $71 \%$ for the manual group).$^{58}$ More recently, Yu et al provided additional evidence of potential refractive benefits of FLACS over manual procedures in a comparative cohort study using the LensAR platform. ${ }^{59}$
Other studies, however, have not found a clinical refractive advantage for FLACS over manual procedures..$^{5,19,22,56}$ One of the difficulties in statistically proving refractive benefits is that while many studies show a trend toward FLACS, very large numbers will be required to reach statistical significance due to the excellent refractive results with manual phacoemulsification. Improving on outcomes, which approach the upper limits of current IOL technology and calculations, suggest that although FLACS may provide the optimal opportunity for refractive outcomes, a significant improvement may only be found once IOL technology additionally increases. Mihaltz et al described less IOL tilt following FLACS procedures. Although no significant refractive differences were found, the reduction of higher order aberrations in the study group suggested potentially greater quality of vision. ${ }^{17}$ Similarly, Lawless et al in a comparative group undergoing multifocal IOL insertion found a significantly greater percentage of patients achieving uncorrected vision of $20 / 25$ or better in the FLACS group despite equivalent refractive outcomes. ${ }^{22}$ This series may suggest that until additional technology develops, FLACS may provide particular qualitative advantages in conditions such as premium IOLs that demand better positioning to achieve the full benefits of the current IOLs.

\section{FLACS in diseased eyes}

Improved laser technology and greater surgeon experience has expanded the clinical indications for FLACS. ${ }^{60,61}$ Patients with preexisting endothelial disease, such as Fuch's endothelial dystrophy or previous penetrating keratoplasty, are at a higher risk of endothelial cell loss. Nagy et al reported a single case of a patient with previous penetrating keratoplasty undergoing FLACS. ${ }^{62}$ The FLACS procedure was performed without ultrasound following successful phacofragmentation. Endothelial cell count was stable at all postoperative visits. Significant corneal scarring or smalldiameter grafts may yet preclude a patient from undergoing successful FLACS; however, this remains an individual assessment. Gavris et al similarly described positive results in a small case series undergoing FLACS in eyes with preexisting Fuch's dystrophy. ${ }^{63}$

Floppy iris syndrome was initially described in $2005 .{ }^{64}$ Minimizing intraoperative time and manipulation may reduce the risk of iris prolapse. The potential benefit of using intraoperative mechanical pupil dilators and intracameral adrenaline in conjunction with FLACS has been described. ${ }^{65-69}$

Pseudoexfoliation syndrome (PXF) poses significant risk during cataract surgery. Patients with PXF do not dilate 
Table 2 FLACS in complex cases

\begin{tabular}{ll}
\hline Condition & Literature \\
\hline Anterior capsular contraction & Schweitzer et al ${ }^{76}$ \\
Bag in lens technique & Dick et al ${ }^{77}$ \\
Floppy iris syndrome & Martin et al $^{61}$ \\
Fuchs dystrophy & Martin et al $^{61}$ \\
Nanophthalmia & Martin et al $^{68}$ \\
Pediatric cataract & Dick and Schultz \\
Phacomorphic glaucoma & Kránitz et al ${ }^{79}$ \\
Phacovitrectomy & Moya Romero et al, ${ }^{81}$ \\
& Bali et al ${ }^{80}$ \\
Post-penetrating keratoplasty & Gómez-Resa et al ${ }^{82}$ \\
Posterior Polar Cataract & Martin et al ${ }^{61}$ \\
Post-trabeculectomy & Vasavada et al, ${ }^{83}$ Titiyal et al $^{84}$ \\
Primary posterior capsulotomy & Roberts et al ${ }^{85}$ \\
Rescue for capsulorhexis enlargement & Dick and Schultz \\
Traumatic cataract & Dick and Schultz \\
Subluxed lens & Grewal et al ${ }^{88}$ \\
White cataract & Crema et al, ${ }^{89}$ Schultz et al $^{90}$ \\
\hline Abbreviation: & Martin et al, ${ }^{61}$ Schultz et al $^{73}$ \\
\hline
\end{tabular}

Abbreviation: FLACS, femtosecond laser cataract surgery.

well despite pharmacologic devices, and zonular instability increases the potential risk of IOL subluxation and capsular tears. Reduction of intraoperative phacoemulsification time and energy and intraocular surgical manipulation are the further benefits of FLACS. .11,69 $^{2}$

Hypermature and white cataracts are associated with high-risk capsulorhexis, posterior capsule rupture, and excessive endothelial cell loss. ${ }^{70}$ Several studies have described the successful use of FLACS in traumatic and white cataracts. ${ }^{71-73}$ The successful use of FLACS in other complex cases is described in Table 2.

\section{Technological advances}

Since the initial reports in 2009 , the learning curve has been well described, and there has been a dramatic evolution in technology and surgeon experience., 3 Table 3 outlines the

Table 3 Summary of LenSx software and hardware changes since 2012

\begin{tabular}{ll}
\hline Version & Features \\
\hline 2.16 & HD OCT, enhanced resolution \\
& Modified, (smaller) patient interface \\
& Increased treatment zone \\
& SoftFit patient interface \\
& Lower IOP rise during docking \\
& Increased free-floating capsulotomies \\
& Advanced pre-positioning \\
& Additional fragmentation patterns \\
& Verion Digital Marker Link \\
& GUI upgrades \\
& Further fragmentation advancements \\
& LASIK flap capability \\
\hline
\end{tabular}

Abbreviations: HD OCT, high-definition optical coherence tomography; IOP, intraocular pressure; GUI, graphical user interface. changes in LenSx software and hardware since 2012. These changes represent functional benefits that have contributed to safer and more predictable surgery and more consistent outcomes and early studies are now of historical value only and not indicative of current practice and outcomes. Comparisons between various laser platforms at different stages should therefore be approached with caution.

OCT imaging is critical to the planning and delivery of the laser ablation. Figure 1 highlights the increase in resolution and of general abilities across software for the LenSx laser. Version 2.20 provides a zoom-in function for greater appreciation of the ocular structures.

Fragmentation patterns have evolved significantly across units and now enable the surgeon to customize the surgery to type and density of the cataract (Figure 2).

\section{Techniques for improved outcomes Docking}

Avoiding tilt is crucial in reducing the risk of incomplete capsulotomies or suction loss. In patients with a large nose, the head needs to be tilted slightly away to the opposite side, so the nose is clear of the PI and does not obstruct docking. Extra drops of Balanced Salt Solution (BSS) may be placed on the eye to facilitate suction. Asking the patient to open both the eyes often relaxes the facial muscles making insertion of the PI easier. If the lids are very tight, the PI is slid under the lower lid without the use of a speculum, and then the upper edge is slipped under the upper lid by retracting the lid with a finger.

\section{Power settings and laser programming}

Energy settings should be increased for the capsulotomy in the presence of corneal opacities or highly irregular corneal shape to improve the chance of a complete capsulotomy. The corneal incision overlay should always be checked in eyes with a shallow AC or angle closure as the OCT may not detect the peripheral $\mathrm{AC}$ and place the corneal incision through the contiguous peripheral iris. The treatment area needs to be manually changed to ensure that the posterior corneal incision is accurately placed and not involving the iris.

\section{Surgical technique}

Reports of capsular block syndrome have made surgeons aware that the intraocular surgical environment is different during FLACS. ${ }^{75}$ Laser-generated gas increases capsular bag volume, particularly in dense cataracts, and the lasercut capsulotomy seals perfectly to the underlying cortex. During manual capsulorhexis, the AC is filled with OVD; 
however, during FLACS, this is not required as the capsulotomy is created with the laser. OVD may tamponade the $\mathrm{AC}$, and injection of hydrodissection fluid further increases the intracapsular volume creating a perfect storm resulting in capsular block, posterior capsule rupture, and nucleus dislocation. Changing the hydrodissection technique from routine phacoemulsification has eliminated this rare complication. The volume of OVD injected into the AC should be decreased prior to removing laser-cut capsulotomy. Small volumes of fluid should be slowly injected under the anterior capsule with the volume titrated against the visible fluid wave. The capsule is decompressed by elevating the anterior capsule with the tip of cannula to allow fluid to egress, and the AC gently decompressed during hydrodissection by slightly opening the corneal incision with the elbow of the hydrodissection cannula.

A hybrid or grid pattern is recommended for moderateto-dense cataracts. Refractive lens exchange or mild cataracts are best treated with a cylindrical laser pattern. Careful inspection is necessary at the end of the case to inspect for any residual nuclear chip which may be trapped sub-incisionally or under the iris. This is best performed when injecting BSS through the secondary incision to restore the AC. Any case of postoperative inflammation should be considered due to a reattained lens fragment until proven otherwise.

Instilling preoperative or perioperative nonsteroidal anti-inflammatory drug drops and phenylephrine drops immediately following laser treatment avoids pupil constriction. Preoperatively, the maximal pupil dilatation should be measured in the clinic as pupil size is a critical factor in laser planning. The advanced laser systems now allow for the capsulotomy to be safely programmed $0.2-0.3 \mathrm{~mm}$ from the pupil edge.

\section{Conclusion}

The current LenSx platform is more advanced, safer, and faster, and the increasing use of femtosecond lasers worldwide has seen a significant increase in surgeon experience. Peer-reviewed studies and face-to-face instruction courses are now available which can provide the transitioning surgeon with a comprehensive overview of safe and effective surgical techniques. Further research will help clarify whether surgical technique and experience and differences in laser platforms may explain in part the reported difference in capsulotomy quality. The observation of most surgeons is that with experience and improved settings and technology, laser cataract surgery results in a consistently round, intact, accurately sized laser-cut capsulotomy and reduced phaco time and energy. Better, safer technology and more cost-effective business models will further expand the clinical indications and uptake of FLACS.

\section{Disclosure}

The authors report no conflicts of interest in this work.

\section{References}

1. Roberts TV, Lawless M, Chan CC, et al. Femtosecond laser cataract surgery: technology and clinical practice. Clin Exp Ophthalmol. 2013; 41(2):180-186.

2. Talamo JH, Gooding P, Angeley D, et al. Optical patient interface in femtosecond laser-assisted cataract surgery: contact corneal applanation versus liquid immersion. J Cataract Refract Surg. 2013;39(4): 501-510.

3. Mayer WJ, Klaproth OK, Ostovic M, Hengerer FH, Kohnen T. [Femtosecond laser-assisted lens surgery depending on interface design and laser pulse energy: results of the first 200 cases]. Ophthalmologe. 2014;111(12):1172-1177. German.

4. Kerr NM, Abell RG, Vote BJ, Toh T. Intraocular pressure during femtosecond laser pretreatment of cataract. J Cataract Refract Surg. 2013; 39(3):339-342.

5. Hodge C, Bali SJ, Lawless M, et al. Femtosecond cataract surgery: a review of current literature and the experience from an initial installation. Saudi J Ophthalmol. 2012;26(1):73-78.

6. Dooley IJ, O'Brien PD. Subjective difficulty of each stage of phacoemulsification cataract surgery performed by basic surgical trainees. $J$ Cataract Refract Surg. 2006;32(4):604-608.

7. Packer M, Teuma EV, Glasser A, Bott S. Defining the ideal femtosecond laser capsulotomy. Br J Ophthalmol. 2015;99(8):1137-1142.

8. Day AC, Gartry DS, Maurino V, Allan BD, Stevens JD. Efficacy of anterior capsulotomy creation in femtosecond laser-assisted cataract surgery. J Cataract Refract Surg. 2014;40(12):2031-2034.

9. Roberts TV, Lawless M, Sutton G, Hodge C. Anterior capsule integrity after femtosecond laser-assisted cataract surgery. $J$ Cataract Refract Surg. 2015;41(5):1109-1110.

10. Nagy ZZ, Kranitz K, Takacs AI, Miháltz K, Kovács I, Knorz MC. Comparison of intraocular lens decentration parameters after femtosecond and manual capsulotomies. J Refract Surg. 2011;27(8):564-569.

11. Nagy Z, Takacs A, Filkorn T, Sarayba M. Initial clinical evaluation of an intraocular femtosecond laser in cataract surgery. J Refract Surg. 2009;25(12):1053-1060.

12. Friedman NJ, Palanker DV, Schuele G, et al. Femtosecond laser capsulotomy. J Cataract Refract Surg. 2011;37(7):1189-1198.

13. Kranitz K, Takacs A, Mihaltz K, Kovács I, Knorz MC, Nagy ZZ. Femtosecond laser capsulotomy and manual continuous curvilinear capsulorhexis parameters and their effects on intraocular lens centration. J Refract Surg. 2011;27(8):558-563.

14. Szigeti A, Kranitz K, Takacs AI, Miháltz K, Knorz MC, Nagy ZZ. Comparison of long-term visual outcome and IOL position with a single-optic accommodating IOL after 5.5- or 6.0-mm femtosecond laser capsulotomy. J Refract Surg. 2012;28(9):609-613.

15. Mastropasqua L, Toto L, Mattei PA, et al. Optical coherence tomography and 3-dimensional confocal structured imaging systemguided femtosecond laser capsulotomy versus manual continuous curvilinear capsulorhexis. J Cataract Refract Surg. 2014;40(12): 2035-2043.

16. Kranitz K, Mihaltz K, Sandor GL, Takacs A, Knorz MC, Nagy ZZ. Intraocular lens tilt and decentration measured by Scheimpflug camera following manual or femtosecond laser-created continuous circular capsulotomy. J Refract Surg. 2012;28(4):259-263.

17. Mihaltz K, Knorz MC, Alió, et al. Internal aberrations and optical quality after femtosecond laser anterior capsulotomy in cataract surgery. J Refract Surg. 2011;27(10):711-716. 
18. Filkorn T, Kovacs I, Takacs A, Horváth E, Knorz MC, Nagy ZZ. Comparison of IOL power calculation and refractive outcome after laser refractive cataract surgery with a femtosecond laser versus conventional phacoemulsification. J Refract Surg. 2012;28(8):540-544.

19. Toto L, Mastropasqua R, Mattei PA, et al. Postoperative IOL axial movements and refractive changes after femtosecond laser-assisted cataract surgery versus conventional phacoemulsification. J Refract Surg. 2015;31(8):524-530.

20. Mamalis N, Brubaker J, Davis D, Espandar L, Werner L. Complications of foldable intraocular lenses requiring explantation or secondary intervention - 2007 survey update. J Cataract Refract Surg. 2008;34(9): $1584-1591$

21. Menapace R. Entwicklungen der modernen Kataraktchirurgie - eine Übersicht und Bewertung. [Developments in modern cataract surgery - a critical overview]. Ther Umsch. 2016;73(2):53-59. German.

22. Lawless M, Bali SJ, Hodge C, Roberts TV, Chan C, Sutton G. Outcomes of femtosecond laser cataract surgery with a diffractive multifocal intraocular lens. J Refract Surg. 2012;28(12):859-864.

23. Auffarth GU, Reddy KP, Ritter R, Holzer MP, Rabsilber TM. Comparison of the maximum applicable stretch force after femtosecond laser-assisted and manual anterior capsulotomy. $J$ Cataract Refract Surg. 2013;39(1):105-109.

24. Abell RG, Davies PE, Phelan D, Goemann K, McPherson ZE, Vote BJ. Anterior capsulotomy integrity after femtosecond laser-assisted cataract surgery. Ophthalmology. 2014;121(1):17-24.

25. Bala C, Xia Y, Meades K. Electron microscopy of laser capsulotomy edge: interplatform comparison. J Cataract Refract Surg. 2014;40(8): 1382-1389.

26. Mastropasqua L, Toto L, Calienno R, et al. Scanning electron microscopy evaluation of capsulorhexis in femtosecond laser-assisted cataract surgery. J Cataract Refract Surg. 2013;39(10):1581-1586.

27. Al Harthi K, Al Shahwan S, Al Towerki A, Banerjee PP, Behrens A, Edward DP. Comparison of the anterior capsulotomy edge created by manual capsulorhexis and 2 femtosecond laser platforms: scanning electron microscopy study. J Cataract Refract Surg. 2014;40(12):2106-2112.

28. Unal M, Yücel I, Sarici A, et al. Phacoemulsification with topical anesthesia: resident experience. J Cataract Refract Surg. 2006;32(8): 1361-1365.

29. Ng DT, Rowe NA, Francis IC, et al. Intraoperative complications of 1000 phacoemulsification procedures: a prospective study. J Cataract Refract Surg. 1998;24(10):1390-1395.

30. Marques FF, Marques DM, Osher RH, Osher JM. Fate of anterior capsule tears during cataract surgery. J Cataract Refract Surg. 2006;32(10): $1638-1642$.

31. Bhagat N, Nissirios N, Potdevin L, et al. Complications in residentperformed phacoemulsification cataract surgery at New Jersey Medical School. Br J Ophthalmol. 2007;91(10):1315-1317.

32. Lundstrom M, Behndig A, Kugelberg M, Montan P, Stenevi U, Thorburn W. Decreasing rate of capsule complications in cataract surgery: eight-year study of incidence, risk factors, and data validity by the Swedish National Cataract Register. J Cataract Refract Surg. 2011; 37(10):1762-1767.

33. Bali SJ, Hodge C, Lawless M, Roberts TV, Sutton G. Early experience with the femtosecond laser for cataract surgery. Ophthalmology. 2012;119(5):891-899.

34. Scott WJ. Re: Abell et al.: Anterior capsulotomy integrity after femtosecond laser-assisted cataract surgery (Ophthalmology 2014;121:17-24). Ophthalmology. 2014;121(7):e35-e36.

35. Pantanelli SM, Diakonis VF, Al-Mohtaseb Z, et al. Anterior capsulotomy outcomes: a comparison between two femtosecond laser cataract surgery platforms. J Refract Surg. 2015;31(12):821-825.

36. Toto L, Calienno R, Curcio C, et al. Induced inflammation and apoptosis in femtosecond laser-assisted capsulotomies and manual capsulorhexes: an immunohistochemical study. J Refract Surg. 2015;31(5):290-294.

37. Kovacs I, Kranitz K, Sandor GL, et al. The effect of femtosecond laser capsulotomy on the development of posterior capsule opacification. J Refract Surg. 2014;30(3):154-158.
38. Wertheimer C, Kreutzer TC, Dirisamer M, et al. Effect of femtosecond laser-assisted lens surgery on posterior capsule opacification in the human capsular bag in vitro. Acta Ophthalmol. Epub 2016 Jun 11.

39. Conrad-Hengerer I, Hengerer FH, Schultz T, Dick HB. Effect of femtosecond laser fragmentation on effective phacoemulsification time in cataract surgery. J Refract Surg. 2012;28(12):879-883.

40. Reddy KP, Kandulla J, Auffarth GU. Effectiveness and safety of femtosecond laser-assisted lens fragmentation and anterior capsulotomy versus the manual technique in cataract surgery. $J$ Cataract Refract Surg. 2013;39(9):1297-1306.

41. Abell RG, Kerr NM, Vote BJ. Toward zero effective phacoemulsification time using femtosecond laser pretreatment. Ophthalmology. 2013; 120(5):942-948.

42. Mayer WJ, Klaproth OK, Hengerer FH, Kohnen T. Impact of crystalline lens opacification on effective phacoemulsification time in femtosecond laser-assisted cataract surgery. Am J Ophthalmol. 2014;157(2): 426.e1-432.e1.

43. Conrad-Hengerer I, Hengerer FH, Schultz T, Dick HB. Effect of femtosecond laser fragmentation of the nucleus with different softening grid sizes on effective phaco time in cataract surgery. $J$ Cataract Refract Surg. 2012;38(11):1888-1894.

44. Nagy ZZ, McAlinden C. Femtosecond laser cataract surgery. Eye Vis (Lond). 2015;2:11.

45. Conrad-Hengerer I, Al Juburi M, Schultz T, Schultz T, Hengerer FH, Dick HB. Corneal endothelial cell loss and corneal thickness in conventional compared with femtosecond laser-assisted cataract surgery: threemonth follow-up. J Cataract Refract Surg. 2013;39(9):1307-1313.

46. Chen X, Chen K, He J, Yao K. Comparing the curative effects between femtosecond laser-assisted cataract surgery and conventional phacoemulsification surgery: a meta-analysis. PLoS One. 2016;11(3):e0152088.

47. Takacs AI, Kovacs I, Mihaltz K, Filkorn T, Knorz MC, Nagy ZZ. Central corneal volume and endothelial cell count following femtosecond laser-assisted refractive cataract surgery compared to conventional phacoemulsification. J Refract Surg. 2012;28(6):387-391.

48. Pahlitzsch M, Torun N, Pahlitzsch ML, et al. Impact of the femtosecond laser in line with the femtosecond laser-assisted cataract surgery (FLACS) on the anterior chamber characteristics in comparison to the manual phacoemulsification. Semin Ophthalmol. Epub 2016 Apr 19.

49. Nagy ZZ, Ecsedy M, Kovacs I, et al. Macular morphology assessed by optical coherence tomography image segmentation after femtosecond laser-assisted and standard cataract surgery. J Cataract Refract Surg. 2012;38(6):941-946.

50. Ewe SY, Oakley CL, Abell RG, Allen PL, Vote BJ. Cystoid macular edema after femtosecond laser-assisted versus phacoemulsification cataract surgery. J Cataract Refract Surg. 2015;41(11):2373-2378.

51. Oakley C, Ewe SY, Vote BJ. Incidence of cystoid macular edema in femtosecond laser-assisted cataract surgery compared with manual cataract surgery. J Cataract Refract Surg. 2015;41(6):1332.

52. Levitz L, Reich J, Roberts TV, Lawless M. Incidence of cystoid macular edema: femtosecond laser-assisted cataract surgery versus manual cataract surgery. J Cataract Refract Surg. 2015;41(3):683-686.

53. Masket S, Sarayba M, Ignacio T, Fram N. Femtosecond laser-assisted cataract incisions: architectural stability and reproducibility. J Cataract Refract Surg. 2010;36(6):1048-1049.

54. Mastropasqua L, Toto L, Mastropasqua A, et al. Femtosecond laser versus manual clear corneal incision in cataract surgery. J Refract Surg. 2014;30(1):27-33.

55. Mayer WJ, Klaproth OK, Hengerer FH, et al. In vitro immunohistochemical and morphological observations of penetrating corneal incisions created by a femtosecond laser used for assisted intraocular lens surgery. J Cataract Refract Surg. 2014;40(4):632-638.

56. Nagy ZZ, Dunai A, Krantz K, et al. Evaluation of femtosecond laserassisted and manual clear corneal incisions and their effect on surgically induced astigmatism and higher-order aberrations. J Refract Surg. 2014;30(8):522-525.

57. Donnenfeld E. Incisional techniques: age-guided femtosecond laser cataract surgery. Eurotimes. 2012;17(2). 
58. Conrad-Hengerer I, Al-Sheikh M, Hengerer FH, Schultz T, Dick HB. Comparison of visual recovery and refractive stability between femtosecond laser-assisted cataract surgery and standard phacoemulsification: six-month follow-up. J Cataract Refract Surg. 2015;41(7): $1356-1364$.

59. Yu AY, Ni LY, Wang QM, et al. Preliminary clinical investigation of cataract surgery with a noncontact femtosecond laser system. Lasers Surg Med. 2015;47(9):698-703.

60. Hatch KM, Talamo JH. Laser-assisted cataract surgery: benefits and barriers. Curr Opin Ophthalmol. 2014;25(1):54-61.

61. Martin AI, Hodge C, Lawless M, et al. Femtosecond laser cataract surgery: challenging cases. Curr Opin Ophthalmol. 2014;25(1):71-80.

62. Nagy ZZ, Takacs AI, Filkorn T, et al. Laser refractive cataract surgery with a femtosecond laser after penetrating keratoplasty: case report. $J$ Refract Surg. 2013;29(1):8.

63. Gavris M, Horge I, Avram E, et al. Fuchs endothelial corneal dystrophy: is femtosecond laser-assisted cataract surgery the right approach? Rom J Ophthalmol. 2015;59(3):159-163.

64. Chang DF, Campbell JR. Intraoperative floppy iris syndrome associated with tamsulosin. J Cataract Refract Surg. 2005;31(4):664-673.

65. Conrad-Hengerer I, Hengerer FH, Schultz T, Dick HB. Femtosecond laser-assisted cataract surgery in eyes with a small pupil. J Cataract Refract Surg. 2013;39(9):1314-1320.

66. Dick HB, Gerste RD. Plea for femtosecond laser pre-treatment and cataract surgery in the same room. J Cataract Refract Surg. 2014;40(3): 499-500.

67. Dick HB, Schultz T. Laser-assisted cataract surgery in small pupils using mechanical dilation devices. J Refract Surg. 2013;29(12):858-862.

68. Martin AI, Hughes P, Hodge C. First report of femtosecond laser cataract surgery in a nanophthalmic eye. Clin Exp Ophthalmol. 2014;42(5): 501-502.

69. Lawless M. Femtosecond laser cataract in diseased eyes. In: Chakrabarti A, editor. Cataract Surgery in Diseased Eyes. New Delhi: Jaypee Brothers Medical Publishers; 2014:182-188.

70. Vasavada A, Singh R, Desai J. Phacoemulsification of white mature cataracts. J Cataract Refract Surg. 1998;24(2):270-277.

71. Nagy ZZ, Kranitz K, Takacs A, Filkorn T, Gergely R, Knorz MC. Intraocular femtosecond laser use in traumatic cataracts following penetrating and blunt trauma. J Refract Surg. 2012;28(2):151-153.

72. Conrad-Hengerer I, Hengerer FH, Joachim SC, Schultz T, Dick HB Femtosecond laser-assisted cataract surgery in intumescent white cataracts. J Cataract Refract Surg. 2014;40(1):44-50.

73. Schultz T, Dick HB. Laser-assisted mini-capsulotomy: a new technique for intumescent white cataracts. J Refract Surg. 2014;30(11): 742-745.

74. Nagy ZZ. New technology update: femtosecond laser in cataract surgery. Clin Ophthalmol. 2014;8:1157-1167.
75. Roberts TV, Sutton G, Lawless MA, et al. Capsular block syndrome associated with femtosecond laser assisted cataract surgery. J Cataract Refract Surg. 2011;37:2068-2070.

76. Schweitzer C, Tellouck L, Gaboriau T, Leger F. Anterior capsule contraction treated by femtosecond laser capsulotomy. J Refract Surg. 2015;31(3):202-204.

77. Dick HB, Canto AP, Culbertson WW, Schultz T. Femtosecond laserassisted technique for performing bag-in-the-lens intraocular lens implantation. J Cataract Refract Surg. 2013;39(9):1286-1290.

78. Dick HB, Schultz T. Femtosecond laser-assisted cataract surgery in infants. J Cataract Refract Surg. 2013;39(5):665-668.

79. Kránitz K, Takács AI, Gyenes A, et al. Femtosecond laser-assisted cataract surgery in management of phacomorphic glaucoma. J Refract Surg. 2013;29(9):645-648.

80. Bali SJ, Hodge C, Chen S, Sutton G. Femtosecond laser assisted cataract surgery in phacovitrectomy. Graefes Arch Clin Exp Ophthalmol. 2012;250(10):1549-1551.

81. Moya Romero JO, Ochoa Máynez GA, Cantero Vergara MA, Gómez Cortes CA. Femtophacovitrectomy. Case series and description of the technique. Arch Soc Esp Oftalmol. Epub 2016 May 23.

82. Gómez-Resa M, Nieto I, Corcóstegui B. Combined 23-gauge vitrectomy and femtosecond laser-assisted cataract surgery. Ophthalmic Res. 2014;52(3):141-146.

83. Vasavada AR, Vasavada V, Vasavada S, Srivastava S, Vasavada V, Raj S. Femtodelineation to enhance safety in posterior polar cataracts. J Cataract Refract Surg. 2015;41(4):702-707.

84. Titiyal JS, Kaur M, Sharma N. Femtosecond Laser-assisted Cataract Surgery Technique to Enhance Safety in Posterior Polar Cataract. J Refract Surg. 2015 Dec;31(12):826-828.

85. Roberts TV, Lawless M, Hodge C. Laser-assisted cataract surgery following insertion of a pupil expander for management of complex cataract and small irregular pupil. J Cataract Refract Surg. 2013;39(12): 1921-1924.

86. Dick HB, Schultz T. Primary posterior laser-assisted capsulotomy. $J$ Refract Surg. 2014;30(2):128-133.

87. Dick HB, Schultz T. Femtosecond laser-assisted capsulotomy rescue for capsulorhexis enlargement. J Cataract Refract Surg. 2014;40(10): $1588-1590$.

88. Grewal DS, Basti S, Singh Grewal SP. Customizing femtosecond laserassisted cataract surgery in a patient with a traumatic corneal scar and cataract. J Cataract Refract Surg. 2014;40(11):1926-1927.

89. Crema AS, Walsh A, Yamane IS, Ventura BV, Santhiago MR. Femtosecond laser-assisted cataract surgery in patients with Marfan syndrome and subluxated lens. J Refract Surg. 2015;31(5):338-341.

90. Schultz T, Ezeanosike E, Dick HB. Femtosecond laser-assisted cataract surgery in pediatric Marfan syndrome. J Refract Surg. 2013;29(9): $650-652$.
Clinical Ophthalmology

\section{Publish your work in this journal}

Clinical Ophthalmology is an international, peer-reviewed journal covering all subspecialties within ophthalmology. Key topics include: Optometry; Visual science; Pharmacology and drug therapy in eye diseases; Basic Sciences; Primary and Secondary eye care; Patient Safety and Quality of Care Improvements. This journal is indexed on Submit your manuscript here: http://www.dovepress.com/clinical-ophthalmology-journa

\section{Dovepress}

PubMed Central and CAS, and is the official journal of The Society of Clinical Ophthalmology (SCO). The manuscript management system is completely online and includes a very quick and fair peer-review system, which is all easy to use. Visit http://www.dovepress.com/ testimonials.php to read real quotes from published authors. 